\title{
Library services and
}

\section{national development}

\author{
By William Sheh Wong \\ Asian Librarian \\ University of Illinois, Urbana
}

\section{An interview with Girja Kumar, President of the Indian} Library Association.

$\mathbf{I}$ April 1985, I interviewed Girja Kumar, current president of the Indian Library Association, in his residence on the campus of the Jawaharlal Nehru University, New

Delhi. Because he was still university librarian at that time, our interview was largely concerned with academic libraries. Two months later, immediately after his retirement from the Jawaharlal Nehru University, Professor Kumar was appointed chairman of the Governing Board of the Delhi Public Library. I then communicated to

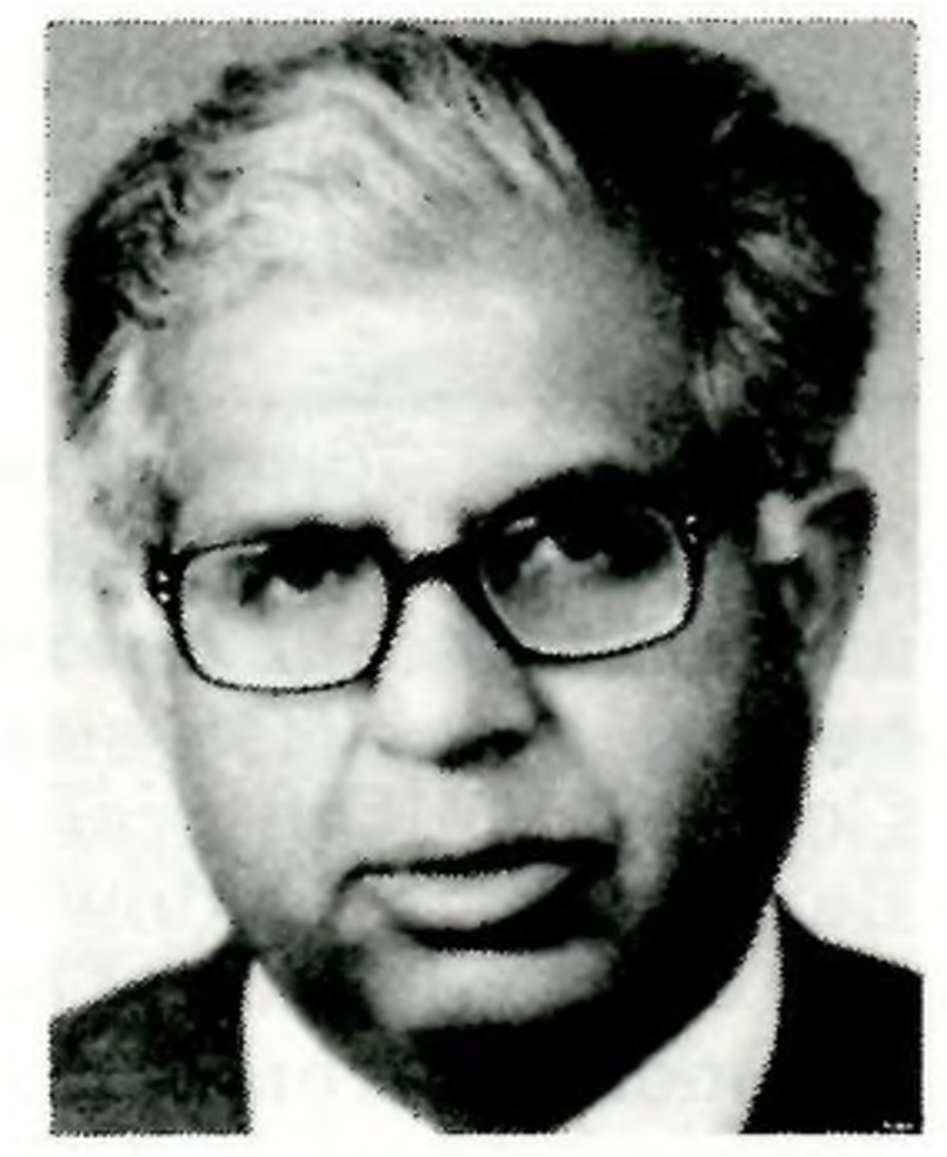

Girja Kumar him readdressing my questions to include a broader spectrum in librarianship. He was very kind to give me a prompt and complete response.

I feel that the views of Professor Kumar are representative of those from the Third World countries. If our assumption is that library services play a key role in national development and social change, the voice of a leading librarian from India should not be ignored. I am, therefore, happy to share one of the most enjoyable fruits of my recent trip to India with my colleagues.

Interviewer: What are the most important and pressing issues and problems in library services in your country?

Kumar: The areas of prime concern to library services in India are the same as those concerning the country as a whole: a) modernization, b) universalization of education, and c) the time-bound developmental process. Libraries have thus to function as an instrument of socioeconomic development in coming years. The special areas of concern to libraries are as follows: a) information management, b) information technology, c) information behavior, and d) information use. Larger emphasis needs to be given to the largely neglected areas of public libraries, school libraries and library services for the handicapped.

Interviewer: As president of ILA, please define the role ILA will play and programs ILA will sponsor in the next five years or so.

Kumar: The Indian Library Association has played a marginal role so far in the scheme of things. It should establish its credibility by providing leadership a) through coordination with agencies concerned with national policy in the country, b) by active involvement in decision-making at local, state and national levels, $\mathrm{c}$ ) by building a fed- 
eral structure for library organizations in the country, d) by coordinating relations with user groups, the book publishing industry, booksellers and governmental agencies, e) by initiating programs of continuing education and research, as well as $\mathbf{f}$ ) by building contacts with international agencies and national organizations of other countries. Priority should be given to a) the development of public libraries, b) introduction of the latest information technology, c) introduction of user education, d) encouragement of user study programs, and e) the development of information networks at local, state and national levels.

Interviewer: You were a top administrator in university and research libraries, and now you are overseeing the governing board of a major public library. What is the relationship between the academic and public libraries in India?

Kumar: Surprising as it may seem, there has hardly been any interaction between academic and public libraries. Public libraries (mostly run by local authorities and financed by State Governments) are considered the poor cousins of academic libraries (financed entirely or substantially by the University Grants Commission). In spite of its handicaps, the public library system is socially more relevant than the academic library system.

Having been involved in running a large academic library, largely a frustrating experience, I find that the academic library system is becoming socially irrelevant with the passage of time. The gap between the information needs of a largely inept user group and the information stored in libraries is widening. There is need for new thinking whereby academic and public library systems become intensely socially relevant and are required to work jointly through legislative action. There is obviously also a need for enunciating the national information and library policy in the near future.

Interviewer: What are your views on international library cooperation, especially between India and the United States?

Kumar: International library cooperation between the United States and India is most desir-

\footnotetext{
${ }^{l}$ All universities in India are public (Centre or State) institutions, with the President of India as their Visitor. The Prime Minister serves as Chancellor for some Centre Universities, and the Governor is Chancellor for all state Universities in his or her state. The chief administrator of the University is the Vice-Chancellor. The University Library is usually administered by the University Library Committee, chaired by the Vice-Chancellor, with the University Librarian as its Secretary. In this administrative structure, a library decision or policy which has been approved by the University Library Committee is final. It clears ways for the University Librarian to run a library smoothly. However, on the negative side, an innovative library administrator may have difficulties in making major policy changes under such a rigid bureaucratic system.
}

able, but it has to be on the basis of equality. Some American librarians and teachers of library science tend to view it as a one-way relationship.

The transfer of technology from the United States, to put it in the widest terms possible, is a subject of most immediate concern in this country. It has to be based on strict quid pro quo. American librarianship can benefit from the work done in India at a conceptual level at best, especially in areas explored in great depth by Dr. S. R. Ranganathan and his close associates.

I feel greatly disappointed at the lack of response received from American librarians to our invitation to participate in the International Conference on Ranganathan's Philosophy (held in New Delhi, November 11-14, 1985) considering the fact that at least 20 other countries have declared their intention to participate. ${ }^{2}$

The future program of cooperation between the two countries should be implemented through the establishment of a joint working group, constituting representatives of the Indian Library Association and the American Library Association.

The provision of facilities for library education in the United States for young Indian librarians and information scientists, exchange of teachers and librarians over extended periods of time, holding of joint seminars and round tables, sponsoring of research programs and provision of consulting services are areas of priority interest. The services of Indian librarians, teachers of library science and information scientists living in the United States would be especially helpful.

Interviewer: What are your research interests? What areas of research are critically needed in your country?

Kumar: I published an important study on the philosophy of user education in $1983 .^{3}$ It went largely unnoticed in the United States. Recently I wrote on the same subject in $R Q{ }^{4} \mathrm{I}$ intend to pursue the same field by conducting advanced re-

\footnotetext{
${ }^{2}$ The theme of the international conference is "Ranganathan's Philosophy: Assessment, Impact, and Relevance." It is organized by the Indian $\mathrm{Li}$ brary Association, co-sponsored by the India Council for Cultural Relations and the Sarada Ranganathan Endowment for Library Science, and was held in New Delhi November 11-14, 1985. For more information, contact the Indian Library Association at the following address: A/40-41, Flat No. 201, Ansal Buildings, Dr. Mukherjee Nagar, Delhi 110009 , India.

${ }^{3}$ Philosophy of User Education was written jointly by his younger brother, Krishan Kumar, chairman and professor of the Department of Library and Information Science at the University of Delhi and published by Vikas Publishing Co., New Delhi, in 1983. Ginja Kumar's publications include 7 books, 3 edited volumes, and 11 chapters or papers contributed to edited works.

${ }^{4}$ Girja Kumar, "Learning Theories, Democracy and User Education," $R Q 24$ (Spring 1985):255-58.
} 


\section{"I used to shudder when patrons requested information on a proceedings paper."}

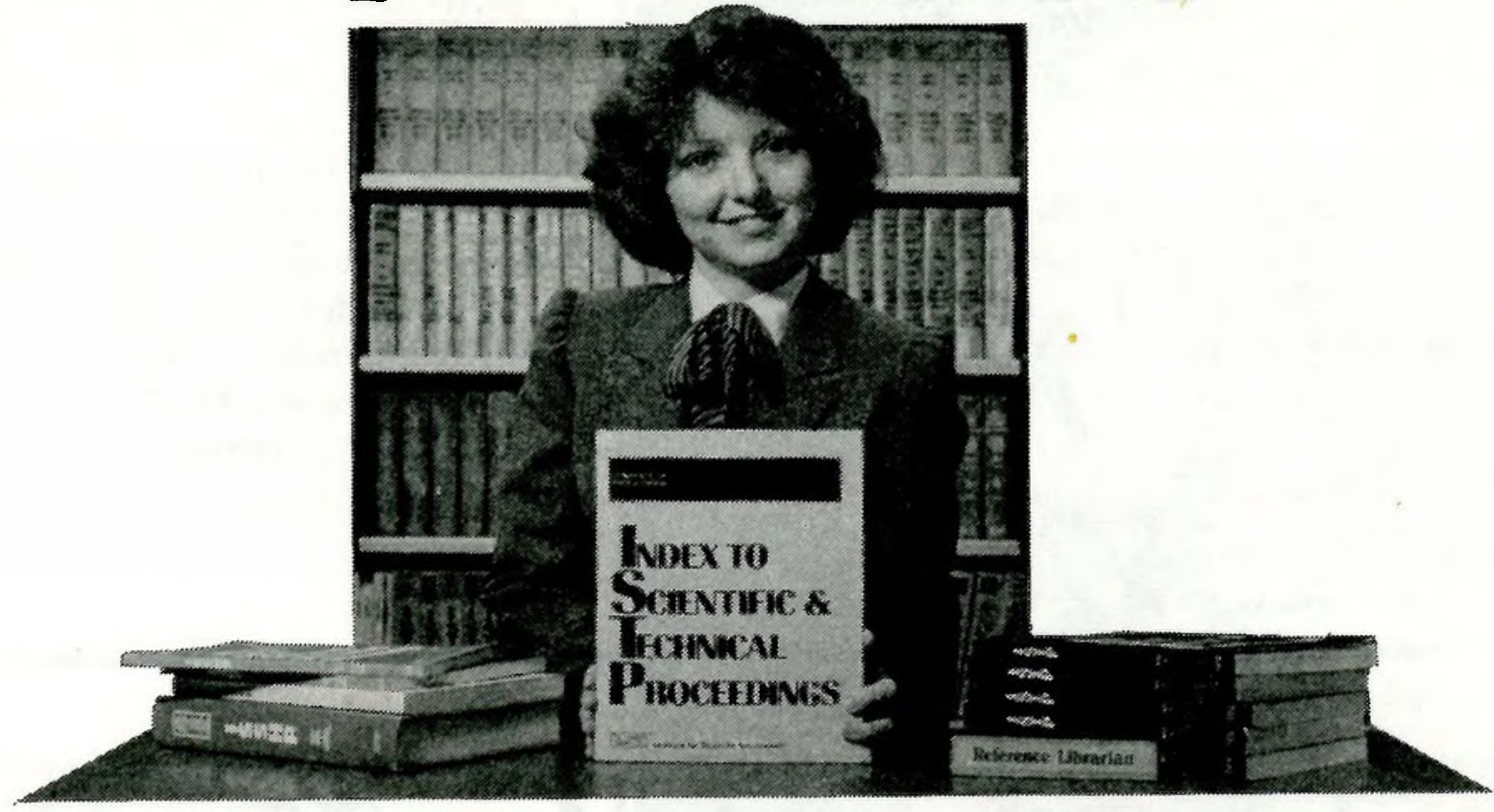

\section{"Now I Reach for ISTP ${ }^{\circledR}$ and ISSHP."}

$\mathbf{N}$ ow you too can get easy access to individual papers published in conference proceedings ... . with the Index to Scientific \& Technical Proceedings ${ }^{\circledR}$ and the Index to Social Sciences \& Humanities Proceedings ${ }^{\circledR}$. Each year, ISTP indexes over 120,000 individual papers, and ISSHP nearly 20,000 . Over $70 \%$ of this material is not indexed in the Science Citation Index ${ }^{\circledR}$ or in the Social Sciences Citation Index ${ }^{\circledR}$.

Since the proceedings literature is generally the first place where early research results appear, you'll find ISTP and ISSHP useful for bibliographic verification, retrospective searches-even for current awareness! Any of six access points quickly lead you to complete descriptions of proceedings and the individual papers presented in them. And the main entries display proceedings in a contents-page format-ideal for easy scanning. Each entry provides the full bibliographic information you need.

Why not make these valuable indexes part of your library's reference collection? A yearly subscription to ISTP is $\$ 725$, and to ISSHP is $\$ 525$.

For more information-and to receive your FREE sample issue of ISTP or ISSHP-just fill out and mail the coupon below. Or call us toll-free 800-523-1850, extension 1371.

Remember, no literature search is complete without checking the proceedings in ISTP or ISSHP.

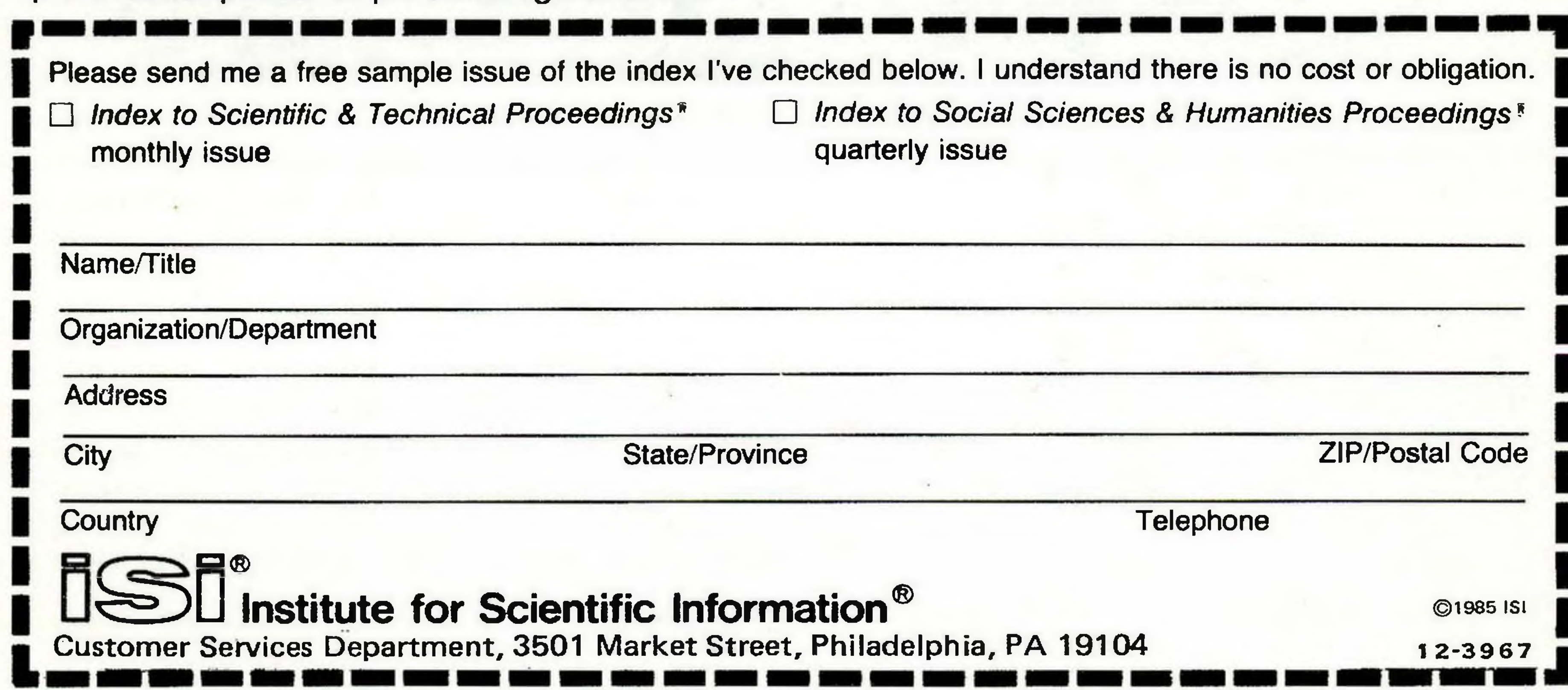


search on information behavior through user studies.

My interests are, however, not confined to the narrow field of library and information science. I propose to undertake a study of the academic and intellectual elite in India soon.

The areas for advanced research in India in the coming years are likely to be as follows: a) information management, b) user education, c) user studies, d) subject indexing, and e) a public libraries system.

Interviewer's note: The keen interests in research and publication seem to be a tradition in Indian academic librarianship. The record which Professor Kumar has produced so far is impressive and he has still been productive after his retirement. Other librarians I met are also very active in research and publishing. Professor Anand P.
Srivastava, librarian of the University of Delhi Library System, whose duties in administration and management are probably the heaviest among academic librarians in the country, has been publishing one monograph dealing with a subject discipline bibliography and research methods every year. Another younger colleague, H. K. Kaul, librarian of the India International Centre in New Delhi, had shown me half a dozen of his published works on Indian literature, and bibliographic and travel guides to particular regions. The most prolific author I have ever met is Attar Chand, reference librarian of the Chinese and Japanese Studies Library at the University of Delhi. As the two-time winner of the President of India's prize in writing, he has published 56 non-fiction books and 20 bibliographies as well as some 25,000 essays and articles that have appeared in newspapers and magazines over a period of 30 years.

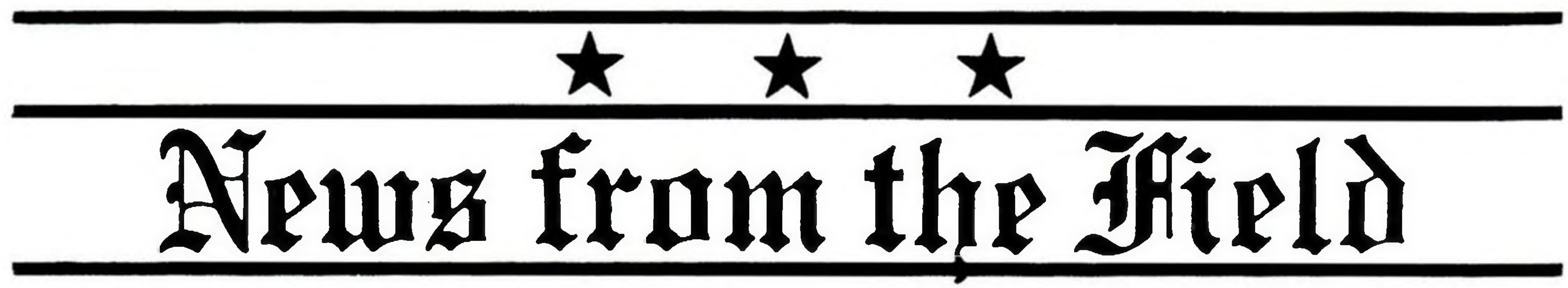

\section{Acquisitions}

- Harvard University, Cambridge, Massachusetts, has acquired two collections of note. The university library has received the first installment of a gift of Urdu books from Pakistani President Zia ulHaqq. The gift was made on behalf of the people of Pakistan in recognition of the contributions made by Harvard Professor Annemarie Schimmel to the study of Urdu literature and Indo-Muslim culture. The books that comprise the first installment of the gift include a 13-volume set of the Urdu journal Nugush, devoted to the study of the prophet $\mathrm{Mu}$ hammad. The remaining installment of the gift will be selected with Professor Schimmel's approval.

The university's Eda Kuhn Loeb Music Library has acquired a collection of more than 175 books relating to Beethoven. The collection was the gift of the university's Fanny Peabody Professor of Music Emeritus Elliott Forbes. The books formed Forbes' working collection, and enhance what is already a considerable collection of works about the composer available in the university's music library.

- Louisiana State University's Hill Memorial Library, Baton Rouge, has received the senate and personal papers of U.S. Senator Russell B. Long (D-LA). The collection contains more than 740,000 items, including correspondence, speeches, press releases, photos, and other political memorabilia. The papers were a gift from Long, who will retire in 1986 after 38 years in the Senate. In addition to the papers of the senator, the gift includes valuable materials regarding the political career and death of Long's father, Huey P. Long, who was assassinated in 1935 . The elder Long had been governor of Louisiana and, at the time of his death, a member of the U.S. Senate. The collection includes the only three known copies of the coroner's report of the death of Carl Weiss, Long's reputed assassin, who was killed by Long's bodyguards after the assassination.

- The United Theological Seminary Library, Dayton, Ohio, has received the collections of two prominent American church historians, Sidney E. Mead and Paul H. Eller. The Mead collection reflects Mead's special interest in church history as it relates to the intellectual, social and cultural history of America, while the Eller collection concerns the former Evangelical Church and the Church of the United Brethren in Christ.

- The University of Missouri, Columbia Libraries has acquired the Anthony C. DeBellis Collection of Italian Literature. The collection contains the work of distinguished poets, historians, scholars and philosophers in contemporary editions from the 16th to the 19th century. The collection, a gift from the Friends of the University Libraries, is named for a former professor of Romance languages at the university.

- The University of Texas at Austin acquired 